\title{
Pengukuran modal intelektual dengan metode kapitalisasi pasar
}

\author{
Rosemarie Sutjiati Njotoprajitno* \\ Program Studi Manajemen, Fakultas Ekonomi, Universitas Kristen Maranatha \\ Jl. Suria Sumantri 65. Bandung. 40164. Indonesia \\ rosemarie.sutjiati@gmail.com \\ Friska Tambunan \\ Program Studi Manajemen, Fakultas Ekonomi, Universitas Kristen Maranatha \\ Jl. Suria Sumantri 65. Bandung. 40164. Indonesia \\ mauliatefrisca@gmail.com \\ *Penulis Korespondensi
}

Submitted: Oct 14, 2018; Reviewed: Jan 10 2019; Accepted: Oct 17, 2019

\begin{abstract}
In order to generate company's income, assets are needed either as input of production process or for other usage. One type of assets is intelectual capital. Many experts in business state the increasing importance of intelectual capital in nowadays business. This research tries to examine intelectual capital value using market capitalization method. This research also tries to examine the effect of intelectual capital to generate profit in a company. This research uses quantitative method by using simple linear regression method to test the effect of intelectual capital to profit. Intelectual capital value is calculated using market capitalization method or market value to book value (MVBV) while company's profit is calculated by return on equity (ROE). The examined companies are from consumer goods companies listed in Indonesia Stock Exchange from 2014 to 2017 that have completed data and generated positive MVBV and ROE. The result shows that Intelectual capital has positive and signficant effect to ROE.
\end{abstract}

Keywords: intelectual capital; market value to book value ratio; return on equity

Abstrak: Dalam rangka menghasilkan pendapatan bagi perusahaan, aset dibutuhkan baik sebagai input proses produksi atau untuk penggunaan lainnya. Salah satu jenis aset adalah modal intelektual. Banyak ahli dalam bisnis menyatakan semakin pentingnya modal intelektual dalam bisnis saat ini. Penelitian ini mencoba menguji nilai modal intelektual menggunakan metode kapitalisasi pasar. Penelitian ini juga mencoba menguji pengaruh modal intelektual untuk menghasilkan laba dalam suatu perusahaan. Penelitian ini menggunakan metode kuantitatif dengan menggunakan metode regresi linier sederhana untuk menguji pengaruh modal intelektual terhadap laba. Nilai modal intelektual dihitung menggunakan metode kapitalisasi pasar atau rasio nilai pasar terhadap nilai buku $(M V B V)$, sementara laba perusahaan dihitung menggunakan rasio Return on Equity (ROE). Beberapa perusahaan yang diteliti adalah dari perusahaan barang konsumsi yang terdaftar di Bursa Efek Indonesia tahun 2014 hingga 2017 yang memiliki data lengkap dan menghasilkan rasio MVBV dan ROE positif. Hasil penelitian menunjukkan bahwa modal intelektual memiliki pengaruh positif dan signifikan terhadap ROE.

Kata kunci: modal intelektual; rasio nilai pasar terhadap nilai buku; return on equity 


\section{PENDAHULUAN}

Tujuan manajemen perusahaan adalah untuk meningkatkan kekayaan para pemegang saham. Untuk mencapainya, maka perusahaan harus mampu menghasilkan laba secara berkelanjutan. Untuk menghasilkan sesuatu maka perlu input. Input pada perusahaan berupa aset atau aktiva baik aset lancar seperti uang kas, persedian maupun aset tetap.

Dari wujudnya, aset dapat dibedakan menjadi aset fisik atau aset berwujud dan aset non fisik atau aset tidak berwujud atau yang sering juga disebut modal intelektual. Modal intelektual mencakup banyak terutama yang bersangkutan dengan sumber daya manusia (SDM) seperti keahlian, pengetahuan dan pengalaman pegawai, modal sosial (social capital) berupa hubungan atau relasional, sistem atau struktur, kekayaan intelektual, dan lainnya. Mengingat modal intelektual ini adalah salah satu bentuk input perusahaan, maka modal intelektual jika dimanfaatkan dengan tepat seharusnya dapat turut mendukung perusahaan dalam menciptakan laba. Saat ini modal intelektual sudah mendapat banyak pengakuan dari berbagai ahli bisnis sebagai salah satu bagian terpenting dari perusahaan.

Untuk menggambarkan hal ini salah satunya adalah perusahaan komputer besar merek Apple yang dimulai oleh Steve Jobs dan rekannya. Aset utama mereka saat itu adalah visi, pengetahuan, kemampuan dan kreativitas mereka, sedangkan aset fisik mereka sangat terbatas. Di kemudian hari Apple menjadi besar dan berkembang. Hal ini artinya nilai seorang manusia yang dapat dianggap modal intelektual yang tinggi ternyata mampu berdampak besar pada kesuksesan perusahaan. Namun, modal intelektual dianggap sulit dinilai karena sulitnya pengukuran, pencatatan termasuk berbagai modal intelektual seperti kemampuan manusia nilainya tidak tetap dan dapat berubah-ubah; tidak seperti aset fisik seperti misalnya mesin yang dapat disusutkan nilainya setiap tahun.

Selama ini banyak ahli meneliti bagaimana cara menilai modal intelektual. Beberapa metode tercipta masing-masing dengan kelebihan dan kelemahannya. Penelitian ini berusaha memeriksa dua hal. Pertama memeriksa nilai atau keadaan modal intelektual pada perusahaan-perusahaan yang diperiksa. Kedua, memeriksa pengaruh modal intelektual dalam menciptakan laba bagi perusahaan.

Makki \& Lodhi (2014) menyatakan bahwa modal intelektual merupakan faktor sukses kritis terhadap kesuksesan sebuah perusahaan sehingga para manajer harus fokus pada pendayagunaan modal intelektual untuk memaksimalkan kekayaan perusahaan dalam jangka panjang. Hasil penelitian Nuryaman (2015: 292) menunjukkan bahwa modal intelektual berpengaruh positif signifikan terhadap profitabilitas perusahaan, sedangkan hasil penelitian Hassanzadeh, Lalepour, \& Imanzadeh (2012: 258) menunjukkan bahwa modal intelektual tidak berpengaruh signifikan terhadap rasio profitabilitas ROE.

Meskipun modal intelektual banyak diakui kegunaannya, namun di Indonesia pendayagunaan modal intelektual masih lemah. Hal ini misalnya dapat dilihat dari daya saing Indonesia pada tahun 2017 dan 2018 dalam hal pendaftaran aplikasi hak paten yang hanya berkisar satu paten per 10 juta penduduk dan Indonesia menduduki peringkat ke-97 dari 130 negara yang diukur (Schwab, 2017). Ketersediaan ilmuwan dan teknisi di Indonesia juga sedang-sedang saja terdapat di peringkat ke-35 dari 137 negara (Schwab, 2017). Dan penggunaan bakat/talent secara efisien pada pasar tenaga kerja juga rendah di peringkat ke-68 dari 137 negara (Schwab, 2017).

\section{TINJAUAN PUSTAKA}

\subsection{Profitabilitas}

Kinerja suatu perusahaan dapat dinilai dari nilai saham perusahaan. Untuk hal ini, Brigham \& Daves (2014) berpendapat bahwa profitabilitas merupakan salah satu penggerak nilai yang memiliki pengaruh terhadap harga saham meskipun pengaruhnya bervariasi di antara berbagai perusahaan yang berbeda dan pada situasi yang berbeda.

Guinan (2010: 288) menyatakan bahwa rasio profitabilitas merupakan suatu golongan metriks finansial yang membantu para investor mengukur kemampuan sebuah bisnis dalam menciptakan atau menghasilkan laba dibandingkan dengan berbagai biaya yang dikeluarkan pada suatu periode.

Rasio profitabilitas yang dipakai dalam penelitian ini untuk menunjukkan kinerja manajemen perusahaan adalah rasio return on equity (ROE). ROE sering digambarkan sebagai tingkat 
pengembalian (rate of return) bagi para investor atau pemegang saham atas investasi mereka di perusahaan yang dihitung dengan formula sebagai berikut.

$R O E=\frac{\text { Laba Bersih }}{\text { Ekuitas }}$

2.2 Modal intelektual

Rasio yang digunakan dalam penelitian ini untuk mengukur modal intelektual adalah rasio market-tobook value (MVBV) yang berasal dari rasio Tobin's Q yang didapat dengan membagi nilai pasar sebuah perusahaan dengan nilai pengganti total aset perusahaan hanya saja karena nilai pengganti ini sulit didapatkan atau diperkirakan maka nilai pengganti kemudian diganti dengan nilai buku perusahaan (Mascarenhas, 2011). Formulanya adalah sebagai berikut.

$M V B V=\frac{\text { Nilai Pasar }}{\text { Nilai Buku Ekuitas }}$

Interpretasi hasil berdasarkan Mascarenhas (2011) dapat dipaparkan sebagai berikut.

1. Rasio MVBV < 1,0. Kondisi ini dapat berarti kepercayaan investor akan perusahaan rendah. Investor menilai perusahaan kurang dari nilai bukunya.

2. Rasio $\mathrm{MVBV}=1,0$. Kondisi ini berarti investor menilai perusahaan setara dengan nilai bukunya.

3. Rasio MVBV > 1,0. Kondisi ini berarti investor menilai perusahaan melebihi nilai semua aset fisiknya sehingga mereka siap membayar premium atau harga lebih karena modal intelektual yang dimiliki perusahaan seperti berbagai inti bisnis perusahaan, produk inti, inovasi baru, hak paten inti, prosedur dan rutinitas organisasional, jejaring atau aliansi strategis, pasar yang dimiliki, serta usaha bersama perusahaan (joint venture).

Investor dapat menilai berbagai modal intelektual ini sangat tinggi sehingga batas atasnya adalah tidak terbatas $(0 \leq$ Rasio $\leq \infty)$. Jika sebuah perusahaan memiliki rasio Market-to-book Value (MVBV) sebesar 3,5. Dari nilai ini mengingat aset fisik sebesar 1,0 dan aset non fisik (modal intelektual) sebesar 2,5 (yang didapat dari 3,5 dikurangi 1,0). Jumlah modal intelektual dari keseluruhan nilai perusahaan adalah 0,7143 (yang didapat dari 2,3 dibagi 3,5). Hal ini berarti lebih dari 70 persen adalah berupa modal intelektual. Lebih jauh, untuk beberapa perusahaan seperti Google, Microsoft, Facebook, modal intelektual jauh lebih berarti daripada aset fisiknya karena mereka menciptakan penghasilan dari modal intelektual.

Perusahaan Micosoft yang tertera pada Tabel 1 berhasil merangkai sistem operasi Windows dan paket program Office dinilai memiliki rasio 10,15 kali, yang berarti modal intelektualnya sebesar 0,9014 (yang didapat dari 9,15 dibagi 10,5). Jadi sekitar 90 persen aset perusahaan ini berupa modal intelektual. Jadi nilai bukunya (total aset fisiknya) hanya sekitar 10 persen dari nilai pasarnya sehingga nilai buku sudah tidak tepat untuk menilai perusahaan ini. Hal serupa banyak dialami berbagai perusahaan teknologi lainnya.

Tabel 1. Rasio MVBV beberapa perusahaan teknologi per 8 Agustus 2018

\begin{tabular}{lc}
\hline \multicolumn{1}{c}{ Perusahaan } & Rasio MVBV \\
\hline Microsoft & 10,15 \\
Apple & 8,71 \\
Facebook & 6,74 \\
Google & 5,35 \\
Intel & 3,27 \\
\hline
\end{tabular}

Sumber: YCharts (2019)

2.3 Hipotesis penelitian

1. $\mathrm{H}_{\mathrm{a}}$ : Berbagai perusahaan yang diteliti memiliki modal intelektual yang baik $\mathrm{H}_{0}$ : Berbagai perusahaan yang diteliti memiliki intelektual yang rendah

2. $\mathrm{H}_{\mathrm{a}}$ : Modal intelektual memiliki pengaruh signifikan terhadap ROE $\mathrm{H}_{0}$ : Modal intelektual tidak memiliki pengaruh signifikan terhadap ROE 
2.4 Kriteria penilaian

1. Dalam penilaian modal intelektual, jika rata-rata total dari rata-rata 4 tahun rasio modal intelektual (MVBV) perusahaan-perusahaan yang diperiksa lebih besar daripada 1,0, maka modal intelektual perusahaan yang diperiksa baik karena investor menilai perusahaan melebihi nilai semua aset fisiknya sehingga mereka siap membayar premium atau harga lebih karena modal intelektual yang dimiliki perusahaan (Mascarenhas, 2011).

2. Uji regresi menggunakan tingkat signifikansi 5 persen. Oleh karena itu, jika nilai $t$ uji lebih kecil dari 0,05 maka $\mathrm{H}_{0}$ ditolak dan $\mathrm{H}_{\mathrm{a}}$ diterima (Malik, 2016: 54) yang artinya modal intelektual memiliki pengaruh signifikan terhadap ROE.

\section{METODE}

3.1 Populasi, sampel, dan sumber data

Penelitian ini merupakan penelitian populasi yang berupa berbagai perusahaan barang konsumsi yang terdaftar di Bursa Efek Indonesia pada tahun 2014 hingga 2017. Penelitian ini merupakan penelitian kuantitatif yang disertai studi literatur. Data pada penelitian ini merupakan data sekunder yang diambil dari situs Bursa Efek Indonesia (BEI). Secara spesifik data diambil dari laporan tahunan saham dan juga ringkasan kinerja perusahaan tercatat.

\subsection{Definisi operasional variabel}

Variabel bebas dalam penelitian ini adalah rasio MVBV. Rasio ini berasal dari rasio Tobin's Q yang didapat dengan membagi nilai pasar sebuah perusahaan dengan nilai pengganti total aset perusahaan. Namun karena nilai pengganti ini sulit diperkirakan maka nilai ini diganti dengan nilai buku perusahaan (Mascarenhas, 2011). Variabel terikatnya adalah rasio profitabilitas return on equity (ROE). Rasio profitabilitas ini merupakan suatu golongan metriks finansial yang membantu para investor mengukur kemampuan sebuah bisnis dalam menghasilkan laba dibandingkan dengan berbagai biaya yang dikeluarkan pada suatu periode (Guinan, 2010: 288).

\subsection{Metode analisis data}

Data yang diperoleh kemudian diolah sesuai dengan rumus MVBV. Hasilnya akan memperlihatkan kondisi modal intelektual perusahaan-perusahaan yang diperiksa. Selanjutnya juga akan dicari pengaruh modal intelektual (MVBV) terhadap ROE menggunakan regresi linier sederhana dengan bantuan program IBM SPSS 20. Uji regresi linier sederhana mensyaratkan uji asumsi klasik seperti uji linieritas, uji normalitas, uji heterokedastisitas, dan uji otokorelasi. Uji multikolinieritas tidak dilakukan karena merupakan prasyarat uji regresi linier berganda bukan uji regresi linier sederhana

\section{HASIL DAN PEMBAHASAN}

4.1 Analisis rasio modal intelektual (MVBV)

Dari hasil Tabel 2 diketahui bahwa pada umumnya sampel perusahaan memiliki modal intelektual yang baik. Hal ini disebabkan karena mayoritas memiliki nilai rata-rata 1,0 ke atas. Rata-rata total modal intelektual seluruh perusahaan yang diperiksa adalah 3,63 yang lebih besar dari 1,0 artinya untuk hipotesis pertama $\mathrm{H}_{0}$ ditolak dan $\mathrm{H}_{\mathrm{a}}$ diterima. Artinya perusahaan-perusahaan yang diteliti memiliki modal intelektual yang baik.

Tabel 2. Rata-rata empat tahun indeks modal intelektual (MVBV)

\begin{tabular}{lrrrrr}
\hline Kode & 2014 & 2015 & 2016 & 2017 & Rerata \\
\hline LMPI & 0,44 & 0,28 & 0,34 & 0,41 & 0,37 \\
CEKA & 0,87 & 0,66 & 0,94 & 0,88 & 0,84 \\
YFA & 0,77 & 0,62 & 1,64 & 0,90 & 0,98 \\
WIIM & 1,60 & 0,99 & 0,96 & 0,62 & 1,04 \\
CINT & 1,26 & 1,08 & 0,99 & 0,98 & 1,08 \\
AISA & 2,05 & 1,00 & 1,58 & 0,35 & 1,25 \\
INDF & 1,45 & 1,10 & 1,55 & 1,46 & 1,39
\end{tabular}




$\begin{array}{lrrrrr}\text { SKLT } & 1,36 & 1,59 & 1,28 & 2,46 & 1,66 \\ \text { DLVA } & 1,97 & 1,52 & 1,84 & 1,95 & 1,82 \\ \text { ADES } & 2,80 & 1,91 & 1,60 & 1,28 & 1,90 \\ \text { TCID } & 2,79 & 2,03 & 1,44 & 1,95 & 2,05 \\ \text { TSPC } & 3,15 & 1,80 & 1,94 & 1,66 & 2,14 \\ \text { SKBM } & 3,08 & 2,75 & 1,65 & 1,23 & 2,18 \\ \text { SIDO } & 3,61 & 3,18 & 3,06 & 2,99 & 3,21 \\ \text { ULTJ } & 4,92 & 4,27 & 3,95 & 3,59 & 4,18 \\ \text { STTP } & 4,79 & 2,31 & 3,82 & 4,26 & 4,30 \\ \text { KAEF } & 4,75 & 2,69 & 6,54 & 6,18 & 5,04 \\ \text { ICBP } & 5,26 & 5,01 & 5,61 & 5,20 & 5,27 \\ \text { DLTA } & 9,33 & 5,32 & 4,37 & 3,48 & 5,63 \\ \text { MYOR } & 4,74 & 5,63 & 6,38 & 6,71 & 5,87 \\ \text { MERK } & 6,97 & 5,81 & 7,44 & 6,24 & 6,62 \\ \text { KLBF } & 9,30 & 5,90 & 6,01 & 5,97 & 6,80 \\ \text { HMSP } & 27,35 & 13,66 & 13,04 & 17,78 & 17,96\end{array}$

Sumber: Diolah dari data Bursa Efek Indonesia (2018)

Rata-rata indeks modal intelektual PT Langgeng Makmur Industri, Tbk. (LMPI) berada di posisi terendah dari perusahaan-perusahaan yang diperiksa dan rasio modal intelektualnya jauh dibawah 1,0 yaitu 0,37 . Hal ini secara sederhana berarti jika perusahaan ini dijual seluruhnya di pasar saham (tanpa proses likuidasi) dengan nilai ini maka harganya hanya 37 persen dari nilai buku perusahaan (nilai total aset fisik perusahaan).

Kemampuan perusahaan LMPI mendapatkan laba juga termasuk salah satu yang terendah di antara perusahaan-perusahaan lain di industri barang konsumsi walaupun sisi positifnya perusahaan masih mampu menjaga perolehan laba dari data ringkasan kinerja perusahaan oleh Bursa Efek Indonesia (2018). ROE perusahaan ini berturut-turut dari tahun 2014 hingga 2017 adalah 0,11 persen; 0,99 persen; 1,7 persen; dan 0,51 persen. Jadi rata-rata ROE per tahun ada di bawah kisaran satu persen. Jika ROE satu persen, hal ini dapat dibayangkan secara sederhana (tidak mempertimbangkan tingkat bunga dan lainnya) bahwa untuk mengembalikan 100 persen ekuitas akan dibutuhkan waktu 100 tahun. Banyak investor akan lebih memilih berinvestasi pada deposito bank yang selain lebih aman. Sebagai data tambahan, tingkat bunga deposito per September 2018 ini empat hingga tujuh persen (Kontan, 2018).

Produk yang diproduksi LMPI seperti peralatan rumah tangga dan aluminium masih tergolong umum dan perbedaannya tidak menyolok dibandingkan dengan produk pesaing sehingga kompetisinya ketat dan berdampak pada terbatasnya angka penjualan. Jadi peranan modal intelektual dalam menciptakan produk yang unggul masih terbatas di perusahaan ini. Hal ini cocok dengan pendapat sekretaris perusahaan LMPI, Hendri Subianto, yang mengemukakan salah satu langkah perusahaan ke depan dalam mengatasi kesulitan penjualan adalah dengan menggenjot produk yang memberi nilai tambah lebih tinggi dan lebih fashionable yang menyasar segmen menengah atas (Lestari, 2017). Pernyataan ini menunjukkan bahwa perusahaan menyadari bahwa ke depan mereka perlu lebih kreatif dan dalam penciptaan produk dan lebih melibatkan strategi diversifikasi produk, penentuan target pasar dan strategi penjualan yang lebih baik yang artinya perusahaan membutuhkan modal intelektual yang lebih besar dari yang sudah ada saat ini.

Perusahaan yang memiliki nilai modal intelektual terbesar adalah PT HM Sampoerna, Tbk. (HMSP) dengan nilai MVBV sebesar 17,96. Hal ini secara sederhana berarti jika HMSP dijual seluruhnya di pasar saham (tanpa proses likuidasi) dengan nilai ini maka harganya 17,96 kali lebih besar dari nilai buku perusahaan (nilai total aset fisik perusahaan). Hal ini berarti kandungan aset non fisik atau aset tidak berwujudnya sangat besar.

Di tengah beratnya tekanan pada produsen rokok ini seperti pajak cukai yang lebih besar dan larangan merokok pada berbagai tempat, HMSP tetap bernilai tinggi di mata investor. Hal ini dapat dikatakan karena memiliki modal intelektual yang baik. Salah satu modal intelektual perusahaan ini yang mendorong perusahaan ini berkinerja baik adalah kemampuan pihak manajemen perusahaan yang baik mulai dari penciptaan produk yang unik dan disesuaikan dengan konsumennya seperti produk rokok A-Mild dengan delapan variannya yang bahkan dipasarkan sampai ke Malaysia. Selain 
itu, iklan yang kreatif dan mencapai sasaran dengan berbagai jargon seperti "A Mild how low can you go?" (1994-1996) sampai yang terbaru "A Mild nanti juga lo tau karya gue" (2017-sekarang) dan juga dengan mensponsori berbagai festival musik seperti soundrenaline (The Conversation, 2018). Pada era tersebut, iklan tidak boleh menampilkan gambar rokok, tetap menunjukkan kreativitas dan keberhasilan perusahaan ini sampai tetap berhasil mempromosikan produknya di atas rata-rata.

Bukti kuat kemampuan pihak manajemen HMSP dapat dilihat dari prestasi keberhasilan pihak manajemen mendapatkan modal kerja dari investor dalam dan luar negeri di tahun 2015 yang mencapai Rp 20,768 triliun atau setara US\$ 1,5 miliar untuk kurs saat itu (Septian, 2016). Modal kerja ini diperoleh dengan cara penawaran umum terbatas (PUT) dalam rangka hak memesan efek terlebih dahulu (HMETD). Prestasi ini menuai penghargaan global yaitu International Financing Review (IFR) Asia Award 2015 dalam kategori 'Indonesia Capital Markets Deal', yang salah satunya adalah oleh karena Sampoerna berhasil menjadi perusahaan dengan kapitalisasi pasar terbesar di Indonesia (Septian, 2016). Bahkan per 22 Februari 2016 Sampoerna telah menjadi perusahaan dengan kapitalisasi pasar terbesar di Indonesia, yaitu Rp 504,238 triliun (Septian, 2016). Selain itu, HMSP juga menjadi perusahaan pembayar pajak terbesar di Indonesia (Septian, 2016). Harus diingat bahwa kemampuan mendapatkan modal kerja dan penempatan modal kerja sangat penting dalam manajemen keuangan dan modal kerja merupakan hal yang sangat penting bagi usaha manapun.

Berikutnya adalah kemampuan HMSP dalam menjaga dan meningkatkan penjualan. Penjualan perusahaan di tahun 2016 adalah sebesar Rp 95,46 trilyun dan di tahun 2017 naik 3,79 persen menjadi Rp 99,09 triliun (Melani, 2018). Hal ini menunjukkan kemampuan divisi penjualan perusahaan dalam menjaga bahkan meningkatkan penjualan. Dengan divisi penjualan sering diibaratkan sebagai ujung tombak sebuah perusahaan hal ini menunjukkan perusahaan ini sebagai perusahaan yang baik dalam hal keuangan.

Lebih lanjut kemampuan dalam penjualan jika digabung dengan kemampuan manajemen dalam manajemen biaya akan berakhir pada kemampuan mendapatkan laba. Kemampuan HMSP mendapatkan laba juga sangat baik. Dari data ringkasan kinerja perusahaan dari Bursa Efek Indonesia (2018). ROE perusahaan ini berturut-turut dari tahun 2014 hingga 2017 adalah 69,59 persen; 32,37 persen; 37,34 persen; dan 40,23 persen. Dengan tingkat pengembalian ekuitas sebesar itu, investor dalam dan luar negeri berlomba-lomba menanamkan modalnya ke perusahaan ini karena modalnya akan cepat kembali dan mendapat keuntungan yang menarik yang jauh di atas tingkat bunga bank yang diperoleh baik dari dividen ataupun dari selisih harga jual saham.

Sebagai tambahan, HMSP juga sempat mendapatkan penghargaan rekor MURI dengan tingkat kecelakaan kerja nihil (tanpa kecelakaan kerja) selama 20 tahun (1996-2016). Hal ini menunjukkan bahwa manajemen keselamatan kerja perusahaan pun baik. Prestasi ini terjadi ditengah situasi masih tinggimya angka kecelakaan kerja di Indonesia. Berdasarkan data Badan Penyelenggara Jaminan Sosial Ketenagakerjaan (BPJS), angka kecelakaan kerja di Indonesia masih sangat tinggi. Hingga akhir 2015, BPJS mencatat sekitar 100.000 kasus kecelakaan kerja di Indonesia per tahun (Melani, 2018).

Walaupun terdapat pro dan kontra mengenai penjualan rokok, namun jika dipandang dari sisi manajemen keuangan dan manajemen perusahaan saja, pihak manajemen keuangan HMSP memiliki kualitas yang sangat baik bahkan masuk ke jajaran prestasi tingkat nasional dan internasional. Dan ini merupakan modal intelektual yang sangat berarti di perusahaan ini. Hal ini menunjukkan bahwa modal intelektual penting agar perusahaan mampu bertahan bahkan mampu bertumbuh di situasi yang sulit sekalipun.

4.2 Hasil uji asumsi klasik

Hasil uji asumsi klasik dapat dirangkum pada Tabel 3 berikut. Uji linearitas menunjukkan hasil bahwa nilai sig. 0,172 lebih besar dari 0,05. Artinya ada hubungan linier variabel bebas terhadap variabel terikat. Hasil uji normalitas menunjukkan nilai Asymp. Sig. (2-tailed) sebesar 0,633 yang lebih besar dari 0,05 yang berarti data yang diuji memiliki distribusi normal. Uji heteroskedastisitas menunjukkan nilai sig. variabel rasio MVBV adalah 0,586 yang lebih besar dari 0,05 yang menunjukkan bahwa tidak terjadi heterokedastisitas. 
Tabel 3. Hasil uji asumsi klasik

\begin{tabular}{lc}
\hline \multicolumn{1}{c}{ Pengujian } & Hasil \\
\hline Uji linearitas & 0,172 \\
Uji normalitas & 0,633 \\
Uji heteroskedastisitas & 0,586 \\
Uji otokorelasi & 1,720 \\
Uji F & 0,000 \\
\hline
\end{tabular}

Sumber: Dirangkum dari hasil pengolahan data menggunakan IBM SPSS 20

Dalam uji otokorelasi, nilai DU (Durbin Upper) data adalah 1,6826 dan nilai DL (Durbin Lower) data adalah 1,6387. Hal ini menunjukkan nilai Durbin Watson adalah 1,720. Karena DW > DL dan 4-DW= $2,2800>$ DL artinya tidak terjadi otokorelasi.

4.3 Hasil uji regresi linear

Setelah seluruh prasyarat uji regresi linear sederhana terpenuhi maka berikutnya dilakukan uji regresi untuk menguji hipotesis. Hasil pengujian regresi dipaparkan pada Tabel 4 berikut.

Tabel 4. Hasil uji regresi linear

\begin{tabular}{lr}
\multicolumn{1}{c}{ Pengujian } & \multicolumn{1}{c}{ Hasil } \\
\hline F & 176,7708 \\
Sig. F & 0,000 \\
R & 0,814 \\
$\mathrm{R}^{2}$ & 0,633 \\
Uji t & 0,000 \\
\hline
\end{tabular}

Sumber: Dirangkum dari hasil pengolahan data menggunakan IBM SPSS 20

Dari hasil pengujian anova, ditemukan nilai $\mathrm{F}$ hitung sebesar 176,7708 dan tingkat signifikansi sebesar 0,000. Karena nilai sig lebih kecil daripada 0,05, maka model regresi dapat dipakai untuk memprediksi variabel ROE.

Nilai korelasi (R) sebesar 0,814 menjelaskan besarnya persentase pengaruh variabel bebas terhadap variabel terikat. Koefisien determinasi $\left(\mathrm{R}^{2}\right)$ sebesar 0,663 mengandung pengertian bahwa pengaruh variabel bebas (MVBV) terhadap variabel terikat (ROE) adalah sebesar 66,3 persen, sedangkan sisanya sebesar 33,7 persen dipengaruhi oleh variabel lain.

Nilai uji $\mathrm{t}$ dengan tingkat signifikan 0,000 lebih kecil daripada 0,05 menggambarkan bahwa hipotesis kedua $\mathrm{H}_{0}$ ditolak dan $\mathrm{H}_{\mathrm{a}}$ diterima. Hal ini menunjukkan bahwa modal intelektual memiliki pengaruh signifikan terhadap ROE. Untuk hubungan ini persamaan regresinya dapat ditulis $\mathrm{Y}=6,996$ $+2,118 \mathrm{X}$.

Hasil ini sesuai dengan penelitian Nuryaman (2015: 292) bahwa modal intelektual berpengaruh positif signifikan terhadap profitabilitas perusahaan. Hal ini juga berarti bahwa pada perusahaan barang konsumsi, umumnya modal intelektual sudah dipahami dan dimanfaatkan dengan baik sehingga turut berperan meningkatkan profitabilitas perusahaan.

Di era sekarang ini terdapat kecenderungan banyak perusahaan manufaktur di negara maju memindahkan lokasi pabriknya di negara berkembang untuk menekan biaya baik biaya bahan baku, biaya gaji, dan lainnya. Hal ini terkesan fokus utama perusahaan saat ini cenderung pada manajemen aset fisiknya. Namun meskipun manajemen aset fisik masih penting, hasil penelitian ini menunjukkan bahwa pada berbagai perusahaan barang konsumsi, modal intelektual dipandang sebagai modal penting bagi perusahaan untuk bertahan pada situasi sulit dan bahkan untuk mencapai kesuksesan.

Hal ini sesuai dengan pendapat Warren Buffet yang sangat suka menggunakan nilai buku pun melihat fenomena banyaknya perusahaan yang nilai pasarnya melebihi nilai buku sehingga kemudian memandang bahwa nilai buku sudah bukan ukuran yang sempurna atau tepat lagi untuk mengukur nilai sebuah perusahaan (Reese, 2017).

Meskipun demikian bukan berarti bahwa perusahaan yang rasio MVBV rendah akan kurang diminati investor. Hal ini tergantung dari tipe investor dan keadaan. Misalnya investor yang yang ingin mendapat persentase saham besar untuk mengambil alih perusahaan akan menyukai saham ini atau 
yang ingin mendapat dana dari bank di mana perusahaan yang dibeli dengan harga di bawah nilai aset fisiknya dan kemudian akan dijaminkan ke bank.

Selain itu rasio MVBV yang rendah juga dapat disebabkan karena turunnya harga aset misalkan perusahaan pertambangan emas dan lainnya yang asetnya berupa emas akan turun ketika harga emas turun dan masih dapat menjadi incaran investor yang percaya harga aset akan naik kembali. Penyebab lain adalah perubahan waktu yang mengubah trend misal industri penyewaan film di Amerika Serikat yang jatuh ketika Youtube diciptakan. Perusahaan dengan rasio MVBV rendah ternyata masih dapat menghasilkan laba dan bertahan untuk waktu yang lama. Jadi untuk menilai kondisi kelayakan perusahaan untuk tujuan investasi perlu juga mempertimbangkan informasi lainnya seperti laba tahunan, aliran kas, dan lainnya.

Jadi jika semua indikator kinerja perusahaan bagus dan perusahaan memiliki dasar yang baik maka rasio MVBV yang rendah bisa jadi hanya menandakan bahwa perusahaan dinilai terlalu rendah (undervalued) sehingga masih menarik untuk dijadikan tujuan investasi. Meskipun demikian rasio MVBV masih menjadi rasio yang dikembangkan untuk menilai modal intelektual sebuah perusahaan karena nilai buku hanya mencantumkan aset fisik saja. Oleh karena itu, perbandingan nilai pasar dan nilai fisik dianggap oleh banyak ahli sebagai nilai modal intelektual termasuk diantaranya brand, SDM, dan lainnya. Contoh sederhananya adalah jika seseorang membeli sebuah hak waralaba (franchise) seperti Kentucky Fried Chicken (KFC) mungkin hanya akan mendapatkan peralatan dan barang dagangan fisik yang nilainya jauh di bawah harga yang dibayarkan. Sisanya berupa izin penggunaan merk, sistem bisnis, resep, pelatihan, dan berbagai sistem lainnya yang bersifat non fisik. Meskipun demikian jika merek tersebut merupakan merek populer yang dianggap dapat mendatangkan laba, maka investor akan bersedia melakukan investasi tersebut meskipun harus membayar premium (harga lebih).

Jadi rasio MVBV yang membandingkan nilai pasar dan nilai buku ini masih disukai untuk menilai modal intelektual sebuah perusahaan. Hasil penelitian ini menunjukkan pentingnya modal intelektual sehingga setiap perusahaan perlu berupaya meningkatkannya.

\section{SIMPULAN DAN SARAN}

\subsection{Simpulan}

Hasil penelitian ini menunjukkan bahwa bahwa perusahaan yang diteliti umumnnya memiliki modal intelektual yang baik. Selain itu, penelitian ini juga menunjukkan bahwa modal intelektual berpengaruh signifikan terhadap profitabilitas perusahaan yang tentunya akan membantu dalam pencapaian tujuan pemaksimalan kekayaan pemegang saham.

Terlebih lagi modal intelektual dapat menjadi pembeda perusahaan sehingga dapat bertahan bahkan memenangkan perrsaingan yang semakin meningkat dari hari ke hari. Dari penelusuran ditemukan bahwa walaupun perusahaan barang konsumsi produknya berupa fisik, namun bukan berarti hanya aset fisik seperti mesin dan persediaan yang menentukan kinerja perusahaan, namun juga aset non fisik seperti brand, kemampuan SDM, sistem, dan lainnya. Perusahaan dengan modal intelektual yang kurang menunjukkan bahwa produknya tidak memiliki hal yang istimewa dan kurang memiliki nilai tambah dan keunggulan. Hal ini kemudian membuat perusahaan tersebut terjebak dalam persaingan ketat yang membuat lesu penerimaan perusahaan. Jika perusahaan pesaing mampu menghasilkan produk yang lebih baik, maka perusahaan akan semakin sulit berkembang dan tidak dapat bertahan. Di era sekarang makin banyak perusahaan sejenis ditambah dengan dan ukuran pasar Indonesia yang besar sehingga menarik perusahaan negara lain untuk memasukinya maka tingkat persaingan akan semakin meninggi. Jadi perusahaan yang ingin bertahan hidup dan memenangkan persaingan tidak boleh hanya berharap pada perlindungan pemerintah melainkan terus berupaya untuk meningkatkan seluruh kualitas perusahaan termasuk modal intelektualnya.

Jadi di sini ditemukan perbedaan antara perusahaan yang modal intelektualnya tinggi dan yang modal intelektualnya rendah yang berdampak pada beberapa hal.

a. Kualitas produk yang diproduksi.

b. Kemampuan memeperoleh pendapatan yang kemudian berpengaruh pada laba perusahaan.

c. Kemampuan perusahaan dalam menghadapi permasalahan dan situasi sulit.

d. Kreativitas perusahaan dalam mencari solusi untuk mengembangkan perusahaan. 


\subsection{Saran}

Pentingnya modal intelektual pada keberlangsungan dan kesuksesan perusahaan membuat perusahaan harus mulai mencoba memerhatikannya. Hal ini dimulai dengan melakukan pemeriksaan atau audit atas apa saja modal intelektual yang sudah mereka miliki baik berupa pengetahuan, SDM unggul, sistem, dan lainnya. Kemudian perusahaan membuat berbagai tindakan untuk mempertahankan dan melindungi kekayaan intelektualnya bahkan menggunkan perlindungan hukum jika diperlukan.

Perusahaan juga dapat mengembangkan atau meningkatkan modal intelektualnya terutama pada area kunci disesuaikan dengan tujuan dan sasaran perusahaan. Modal intelektual dapat diperoleh dengan berbagai macam cara seperi membeli, menggunakan jasa berbagai macam konsultan, merekrut SDM tertentu, dan mengembangkannya melalui berbagai pelatihan. Namun yang penting adalah perusahaan perlu terus memantau agar modal intelektual yang dimiliki benar-benar berguna dan juga dimanfaatkan dengan tepat bagi kebaikan perusahaan.

\section{REFERENSI}

Bursa Efek Indonesia. (2018). Diakses 1 September 2018 dari: https://www.idx.co.id

Brigham, E.F., \& Daves, P.R. (2014). Intermediate Financial Management (12ed.). Boston: Cengage Learning.

Guinan, J. (2010). Investopedia: Cara Mudah Memahami Istilah Investasi. Jakarta: Penerbit Hikmah

Hassanzadeh, R.B., Lalepour, M., \& Imanzadeh, P. (2012). Effect of intellectual capital efficiency on financial performance and market value of companies. Australian Journal of Basic and Applied Sciences, 6(13): pp. 258-266.

Kontan. (2019). Suku Bunga Deposito Diakses 8 Oktober 2019 dari Kontan: https://pusatdata.kontan.co.id/bungadeposito/

Lestari, S.H. (2017). Penjualan Peralatan Rumah Tangga Seret, Langgeng Makmur Bidik Pasar Ekspor. Diakses 28 Agustus 2018 dari Tribune News: http://surabaya.tribunnews.com/2017/06/11/penjualan-peralatan-rumah-tangga-seret-langgengmakmur-bidik-pasar-ekspor.

Makki, M.A.M., \& Lodhi, S.A. (2014), Impact of corporate governance on intellectual capital efficiency and financial performance, Pakistan Journal of Commerce and Social Sciences, 8 (2), pp. 305-330.

Malik, N. (2016). Dinamika Pasar Tenaga Kerja Indonesia. Malang: Penerbitan Universitas Muhammadiyah Malang.

Mascarenhas, O. A. J. (2011). Business Transformation Strategies: The Strategic Leader as Innovation Manager. New Delhi: SAGE Publishing India

Melani, A. (2018). Penjualan HM Sampoerna nyaris Rp100 triliun. Diakses 28 Agustus dari Liputan 6: https://www.liputan6.com/bisnis/ read/3351510/penjualan-hm-sampoerna-nyaris-rp-100-triliun

Nuryaman (2015). The influence of intellectual capital on the firm's value with the financial performance as intervening variable. Procedia - Social and Behavioral Sciences, 211, pp. 292-298.

Reese, J. P. (2017). Book Value - A Buffett Favorite, But Far from Perfect. Diakses 1 September 2018 dari Seeking Alpha: https://seekingalpha.com/article/4060859-book-value-buffett-favorite-farperfect.

Schwab, K. (2017). The Global Competitiveness Report 2017-2018. World Economic Forum.

Septian, D. (2016). HM Sampoerna Jadi Perusahaan Berkapitalisasi Pasar Terbesar di RI. Diakses 28 Agustus 2018 dari Liputan 6: https://www.liputan6.com/bisnis/read/ 2446377/hm-sampoernajadiperusahaan-berkapitalisasi-pasar-terbesar-di-ri.

The Conversation (2018). Perusahaan rokok rayu anak muda dengan konser musik dan media sosial. Diakses 10 Oktober 2019 dari The Conversation: http://theconversation.com/perusahaan-rokokrayu-anak-muda-dengan-konser-musik-dan-media-sosial-94330

YCharts (2019). https://ycharts.com/comp anies. Diakses 10 Oktober 2019 
Jurnal Manajemen Maranatha — Vol. 19 Nomor 1, November (2019) 